\title{
ANALYSIS THE EFFECT OF ELECTRONIC MONEY USE ON VELOCITY OF MONEY: EVIDENCE FROM INDONESIA
}

\author{
Sufi Azhari Pambudi*1 \\ M. Khoerul Mubin²
}

${ }^{1,2}$ Fakultas Ekonomi dan Bisnis, Universitas Airlangga, Indonesia

\begin{abstract}
This study aims to examine the effect of electronic money transactions on the velocity of money in Indonesia. This study uses a quantitative research approach using quarterly time series data for the 2010q1-2018q4 period. Using variable velocity obtained from Gross Domestic Product (GDP) divided by $M 2$, electronic money transactions, GDP per capita, and interest rates using the Error Correction Model (ECM) method. The results show that in the long run variable electronic money transactions, income levels and interest rates are significantly positive. In the short term, interest rates and income levels are significantly positive, while electronic money transactions only have a slight effect on the velocity of money in Indonesia.
\end{abstract}

Keywords: Electronic Money, Velocity of Money, Error Correction

\section{ABSTRAK}

Penelitian ini bertujuan untuk menguji pengaruh transaksi electronic money terhadap kecepatan perputaran uang di Indonesia. Studi ini menggunakan pendekatan penelitian kuantitatif dengan menggunakan data time series quartal periode 2010q1-2018q4. Menggunakan variabel velocity yang didapat dari Gross Domestic Product (GDP) dibagi dengan M2, transaksi electronic money, PDB per kapita, dan tingkat suku bunga dengan menggunakan metode Error Correction Model (ECM). Hasilnya menunjukkan bahwa dalam jangka panjang variabel transaksi electronic money, tingkat pendapatan dan tingkat suku bunga signifikan positif. Pada jangka pendek tingkat suku bunga dan tingkat pendapatan signifikan positif sedangkan transaksi electronic money hanya berpengaruh sedikit kecepatan perputaran uang di Indonesia.

Kata Kunci: Uang Elektronik, Perputaran Uang, Koreksi Kesalahan

JEL: P42; F65

\section{Pendahuluan}

\section{Latar Belakang}

Penggunaan teknologi modern sebagai pembayaran non-cash, baik yang domestik
RIWAYAT ARTIKEL

Tanggal Masuk: 7 April 2020

Tanggal Direvisi: 14 Mei 2020

Tanggal Diterima:

20 Juni 2020

Tersedia Online:

25 Juni 2020

*Korespondensi:

Sufi Azhari Pambudi

E-mail:

sufi@gmail.com

JIET (Jurnal Ilmu Ekonomi Terapan) p-ISSN: 2541-1470; e-ISSN: 2528-1879 DOI: $10.20473 /$ jiet.v5i1.19626

Open access under a Creative Commons Attribution-ShareAlike 4.0 International

(CC BY-SA) 
maupun secara internasional telah mulai berkembang pesat disertai dengan adanya berbagai inovasi yang mulai mengarah pada penggunaanya yang semakin efisien, aman, cepat dan juga nyaman. Teknologi modern sendiri berfokus pada masalah substitusi tunai dengan jenis teknologi yang menggunakan pembaruan alat transaksi untuk kegiatan ekonomi. Perkembangan teknologi yang juga pesat akan selalu dapat memberikan inovasi baru dan inovasi baru diharapkan dapat memberikan solusi baru terhadap masalah yang ada. Tingginya transaksi uang yang beredar di masyarakat serta banyaknya kasus pemalsuan uang, besarnya biaya atas operasional yang dikeluarkan Bank Indonesia pada setiap tahunnya untuk mencetak, menyimpan, mndistribusikan, dan juga dapat memusnahkan uang menjadi latar belakang dari Bank Indonesia untuk mencanangkan sebuah gerakan penggunaan instrumen non tunai. Bank Indonesia memberikan program khusus dalam melakukan transaksi atas kegiatan ekonomi yang diberi nama dengan Gerakan Nasional Non Tunai. Alinea Bank Indonesia memunculkan e-money dilatar belakangi oleh Peraturan Bank Indonesia Nomor 11/12/PBI/2009 sebagai salah satu pendukung agenda Bank Indonesia untuk menciptakan program less cash society di Indonesia. Uang elektronik memiliki potensi dalam membawa efisiensi ke bankir melalui kemudahan layanan bankir mikro dalam suatu proses peningkatan kenyamanan pelanggan. Peluncuran uang elektronik juga diharapkan meningkatkan kegiatan ekonomi dan akan meningkatkan output negara. Uang elektronik difokuskan pada pengurangan risiko sistemik dan juga peningkatan efisiensi penyediaan layanan pembayaran (Suri \& Jack, 2016).

Data dari Bank Indonesia menunjukkan adanya kecenderungan pada pemakaian sistem pembayaran bersifat non tunai yang semakin mulai diminati oleh masyarakat di Indonesia, hal ini dapat terlihat dari adanya peningkatan transaksi electronic money yang beredar di masyarakat. Peningkatan terbesar terjadi pada tahun $2017 q 4$ yaitu sebesar 23.163 .529 satuan pengguna elektronic money. Rata - rata penggunaan electronic money terus meningkat dalam setiap tahunnya namun terjadi penurunan pada tahun 2014q2 dan 2016q1.

Penggunaan electronic money memiliki tingkat efisiensi untuk melakukan proses transaksi jual-beli dan juga memiliki keterkaitan dengan tingkat percepatan uang. Percepatan uang (velocity of money) adalah Rata-rata transaksi berapa kali per tahun (perputaran) dari satu unit mata uang yang digunakan untuk membeli total barang dan jasa yang diproduksi dalam perekonomian (Mishkin, 2009). Teori Irving Fisher yang membahas tentang keterkaitannya antara transaksi uang yang beredar dengan total produksi barang dan jasa (PDB). Jika orang menggunakan uang elektronik akan dapat diasumsikan bahwa akan semakin sedikit uang yang ada di dompet untuk melakukan transaksi dan pendapatan nominal akan naik sebagai akibat dari adanya kecepatan (Mishkin, 2009).

Money supply adalah transaksi uang yang beredar pada perekonomian dan uang tersebut telah siap digunakan bertransaksi. Berdasarkan Keynes mengenai penawaran uang (money supply) yang menyatakan bahwa peningkatan transaksi uang beredar memiliki pengaruh positif terhadap output dan juga pertumbuhan ekonomi.

Kontribusi penelitian ini diharapkan dapat berguna bagi para pengambil keputusan untuk mengembangkan electronic money yang ada di Indonesia. Penelitian ini menggunakan data electronic money yang berbeda dari penelitian sebelumnya atau baru pertama kali digunakan yaitu data rasio electronic money yaitu yang didapat dari data transaksi electronic money dibagi dengan transaksi uang $\mathrm{M} 2$. Sistematika penulisan penelitian ini terbagi menjadi lima bagian yaitu bab 1 berisi tentang penjelasan latar belakang permasalahan serta topik masalah, kesenjangan dan tujuan penelitian, manfaat penelitian, dan sistematika penulisan. Bagian kedua yaitu bab 2 berisi tentang landasan teori tentang uang, evolusi sistem pemba- 
yaran, dan pengertian dari electronic money dan juga bagaimana fungsinya. Bagian ketiga yaitu bab 3 berisi mengenai pendekatan pada penelitian yang digunakan, identifikasi variabel, definisi operasional, jenis dan juga sumber data serta teknik analisis yang digunakan. Bagian keempat yaitu bab 4 berisi mengenai penjelasan gambaran umum dari subyek penelitian, deskripsi hasil penelitian, analisis. Bagian kelima yaitu bab 5 berisi pembahasan kesimpulan dan saran.

\section{Telaah Literatur}

\section{Evolusi Sistem Pembayaran}

Fungsi dan bentuk uang sudah mengalami perubahan dari waktu ke waktu. Hal ini dapat kita cermati bersama melalui evolusi sistem pembayaran. Sistem pembayaran sendiri memiliki beberapa cara tetapi yang dimaksud adalah cara transaksi tersebut dilakukan dalam perekonomian. Sistem pembayaran sendiri sudah mulai berubah demikian pula dengan bentuk uang itu sendiri. Pada awalnya yaitu emas dan sampai adanya uang kertas, logam, dll.

Tahapan evolusi sistem pembayaran di masa ini adalah pada zaman tekhnologi yang sudah maju dan terus berkembang. Meluasnya internet, harga yang terjangkau untuk membeli teknologi dan semakin tinggi pengetahuan seseorang terhadap internet maka dapat memunculkan sistem pembayaran dengan cara yang elektronik. Pembayaran elektronik ini sendiri tidaklah memerlukan biaya yang terlalu mahal dan sangat efisien. Salah satu bentuk dari sistem pembayaran secara elektronik adalah electronic money. Electronic money diciptakan dengan tujuan untuk dapat memudahkan aktivitas masyarakat dalam bertransaksi. Terlebih lagi sekarang electronic money dapat juga disimpan di Smartphone, sehingga electronic money bisa digunakan kapan saja (Hidayati et al., 2006).

\section{Pengertian Uang Elektronik}

Uang elektronik adalah suatu alat pembayaran elektronik yang diperoleh dengan langkah menyetorkan terlebih dahulu setransaksi uang kepada penerbit baik secara langsung maupun tak langsung dan uang yang sudah dimasukkan menjadi nilai uang dalam media uang elektronik yang dinyatakan dalam satuan rupiah atau sebagainya. Uang elektronik juga bisa dikategorikan sebagai alat penyimpan uang yang dimiliki oleh suatu individu dalam bentuk media elektronik.

Uang elektronik memiliki beberapa jenis tapi yang menjadi fokus adalah uang elektronik sebagai media pembayaran. Bank Indonesia (BI) telah menerbitkan beberapa jenis uang elektronik, uang elektronik yang dimaksud berbeda dengan kartu kredit dan kartu debit. Kartu kredit dan debit merupakan kartu dengan single- purpose dan sedangkan uang elektronik yang dimaksud oleh Bank Indonesia adalah uang elektronik yang menggunakan kartu multipropose.

Perbedaan uang elektronik single-purpose dan multi-purpose adalah fungsi dari kartu tersebut. Kartu single-purpose adalah kartu yang hanya dapat digunakan sebagai media melakukan satu jenis transaksi ekonomi dan sedangkan multi-purpose adalah kartu yang dapat digunakan untuk melakukan lebih dari satu jenis transaksi ekonomi (Hidayati et al., 2006).

Kemunculan uang elektronik membuat komposisi money supply menjadi:

$$
\begin{aligned}
& M 1=C O B+D+\text { Float } \\
& M 2=M 1+S+T
\end{aligned}
$$


Keterangan :

$\mathrm{COB}=$ Uang kartal

D = Giro

Float $=$ Monetary Value (E-money)

$\mathrm{S} \quad=$ Uang kuasi berbentuk tabungan

$\mathrm{T} \quad=$ Simpanan berjangka

\section{Perputaran Uang (Velocity of Money)}

Perputaran uang (velocity of money) merupakan besaran percepatan uang yang ada dalam perekonomian. Perputaran uang merupakan cara untuk mengukur tingkat pendapatan nasional dibandingkan dengan perilaku pembeli dengan mengubungkan antara uang, pembelian barang dan jasa. Perputaran uang dapat dinyatakan dalam bentuk perbandingan yakni antara nilai pendapatan nasional bruto (PDB/GDP) terhadap persediaan uang.

Menurut teori Irving Fisher (Fisher, 1911) bahwa percepatan uang adalah konsep untuk menghitung transaksi uang beredar $(\mathrm{M})$ yang terkait dengan tingkat harga $(\mathrm{P})$ dan output agregat $(\mathrm{Y})$. Velocity of money $(\mathrm{V})$ dapat diartikan sebagai transaksi rata- rata kali per tahun dari satu unit mata uang yang digunakan untuk membeli atau total barang dan jasa yang diproduksi dalam perekonomian. Sederhananya percepatan uang dapat menunjukkan berapa kali uang berputar dalam periode tertentu.

\section{Teori Permintaan Uang}

Irving Fisher menguluarkan buku yang berjudul " The Purchasing Power of Money" (Fisher, 1911) merumuskan sebuah teori permintaan atau kuantitas uang sebagai berikut:

$$
M . V=P . T
$$

Dimana:

$\mathrm{M}=$ penawaran uang

$\mathrm{V}=$ perputaran uang

$P=$ tingkat harga

$\mathrm{T}=$ volume barang yang diperdagangkan

Menurut fisher menunjukkan velocity atau kecepatan perputaran uang dapat berubah karena adanya suatu faktor kelembagaan atau faktor teknologi yang berkembang. Pandangan klasik juga berpendapat bahwa nilai suatu barang yang diperdagangkan sama dengan transaksi atas uang yang beredar. Fisher juga menyebutkan bahwa permintaan uang akan sama dengan GDP (permintan barang) (Mishkin, 2004).

Keynes pada buku yang ditulisnya berjudul "The General Theory of Employment, Interest, and Money" (Keynes, 1936) juga memberikan sebuah pandangan yang berbeda dengan pandangan kaum Klasik bahwa motif memegang uang untuk spekulasi itu tidak benar. Teori Keynes menerangkan bahwa konsep memegang uang untuk spekulasi bergantung pada tingkat suku bunga. Tingkat suku juga mempengaruhi permintaan uang untuk tujuan transaksi. Keynes juga menyebutkan bahwa dalam permintaan uang memiliki hubungan yang negatif 
dengan tingkat suku bunga tetapi permintaan uang memiliki hubungan yang positif dengan tingkat pendapatannya (Mishkin, 2004).

Sudut pandang teori ini mengungkapkan permintaan uang sebagai total kekayaan seseorang dan teori ini juga sependapat dengan teori Fisher. Friedman memiliki pendapat bahwa permintaan uang memiliki hubungan yang positif dengan tingkat pendapatan dan memiliki hubungan negatif dengan tingkat kekuatan uang dalam membeli barang (Mishkin, 2004).

Pada 1936 Cambridge mengungkapkan pendapatnya pada teori money demand. Persamaan Cambridge tersebut mulai dikembangkan oleh Marshall dan Pigou. Pada permintaan uang suatu individu.

$$
M d=k P Y
$$

Keterangan :

$\mathrm{Y}=$ pendapatan riil

$\mathrm{P}=$ rata - rata harga pada barang yang di produksi

$\mathrm{K}=$ proporsi uang seseorang untuk dibuat cash

Menurut Cambridge dalam teori mengenai permintaan uang juga memiliki perbedaan dengan hasil pandangan Fisher. Menurut Cambridge tingkat dari suku bunga tidak memiliki pengaruh pada permintaan uang dan sedangkan menurut Fisher tingkat suku bunga memiliki pengaruh pada teori permintaan uang. (Mishkin, 2004)

\section{Studi Terdahulu}

Beberapa penelitian sebelumnya yang memiliki kaitan pada electronic transaction terhadap percepatan uang, diantaranya yaitu penelitian oleh Griffith \& F (2012); Propovska-kamnar (2014); Andresen (2013); Khan \& Craig-Less (2009). Beberapa dari penelitian diatas menyatakan sebuah hasil penelitian bahwa electronic money memiliki pengaruh pada percepetan uang di negara tersebut serta dapat mempengaruhi kebijakan moneter suatu negara. Electronic money dapat memberi pengaruh pada percepatan uang di negara tersebut dikarenakan electronic money yang berada di negara sampel penelitian sudah sangat berkembang dan masyarakat disana sudah dapat mulai menggunakannya untuk kegiatan sehari- hari seperti melakukan transaksi jual-beli, mengendarai transportasi umum hingga cenderung melakukan perjalanan pribadi menggunakan jalan tol.

Penelitian sebelumnya yang membahas mengenai pola pada electronic transaction terhadap percepatan uang, Zhou (2010); Durgun \& Timur (2015); Burke (2002) ini menggunakan sampel di negara China, Turkey, dan Indiana. Beberapa penelitian diatas memiliki hasil penelitian yang dimana electronic money kurang dapat memberi pengaruh pada percepatan uang karena di negara China, Turkey, dan juga Indiana masyarakatnya masih terbilang sedikit yang menggunakan electronic money sehingga transaksi dan volume atas penggunaan electronic money belum dapat memberi pengaruh pada percepatan uang.

Beberapa penelitian sebelumnya oleh Ranjan \& Kar (2014); Zayer \& Al- Tweel (2019); Humphrey, Lawrence, \& Jukka (2002) ; Poon \& Patrick (2001). Beberapa penelitian tersebut menggunakan variabel Velocity, GNP, dan transaksi uang di negara. Variabel GNP dan transaksi uang akan mempengaruhi percepatan uang di negara. Pembahasan penelitian ini juga membahas mengenai bagaimana electronic money mempengaruhi permintaan uang kartal dan giral. Hasil dari beberapa penelitian diatas mengungkapkan bahwa electronic money tidak 
signifikan pada percepatan uang dan electronic money juga tidak mempengaruhi permintaan uang kartal dan giral karena beberapa penelitian diatas memiliki sampel negara yang berkembang dan electronic money masih sedikit yang menggunakan.

Penelitian oleh Mbiti \& David (2019); Raghubir \& Joydeep (2008); Halpin \& Roksana (2009); See-To \& Erik (2018). Penelitian ini dilakukan di negara Amerika dan benua Eropa yaitu negara Inggris, penelitian tersebut menggunakan variabel tingkat suku bunga dan frekuensi tingkat transaksi. Penelitian ini membahas tentang bagaimana electronic mulai masuk ke dalam pasar dan bagaimana respon masyarakat terhadap alat pembayaran baru.Penelitian tersebut membahas bahwa perkembangan electronic money dan bagaimana pengaruh regulasi mengenai electronic money. Perkembangan electronic money di negara Inggris pada tahun-tahun tersebut masih sangatlah muda atau masih terbilang baru, kemudahan yang diberikan electronic money sangat diterima di negara-negara benua Eropa dan salah satunya negara Inggris. Hasil penelitian ini menunjukkan bahwa electronic money mempunyai hal positif dan diterima oleh warga negara Inggris dan electronic money mempengaruhi tingkat konsumsi serta pengeluaran seseorang. Alat pembayaran yang baru yaitu electronic money dapat mempengaruhi tingkat konsumsi dan pengeluaran seseorang karena kelebihan dari electronic money itu sendiri yang lebih mudah dibawa dan lebih efisien digunakan.

\section{Metode Penelitian}

\section{Definisi Operasional Variabel}

\section{Velocity of money $(\mathrm{V})$}

Variabel velocity of money menjadi variabel dependen karena velocity of money atau percepatan uang ini akan dipengaruhi beberapa variabel independen antara lain pendapatan nasional (GDP) dan money supply di negara tersebut. Data yang digunakan berupa data GDP dan M2 diolah menjadi jadi nilai velocity. Data GDP dan M2 diperoleh dari BPS dari tahun 2010 - 2018.

\section{Tingkat suku bunga $(i)$}

Variabel suku bunga menjadi variabel independen karena suku bunga akan mempengaruhi tingkat percepatan uang, dengan semakin tinggi tingkat suku bunga akan tinggi percepatan uang begitu juga sebaliknya jika tingkat suku bunga rendah akan menurunkan tingkat percepatan uang. Data yang digunakan yaitu data bulanan yang diolah menjadi data triwulan. Data suku bunga yang digunakan adalah data suku bunga deposito. Data diperoleh dari situs Bank Indonesia tahun 2010-2018.

\section{Sumber Data}

Data transaksi uang elektronik yang didapat dari situs website Bank Indonesia. Data GDP berasal dari Internasional Monetary Fund dan data Money Supply berupa data yang ada di BPS. Data variabel velocity berasal dari pembagian dari data GDP dengan data money supply.

\section{Model Analisis}

Model analisis yang digunakan untuk menguji pengaruh electronic money terhadap tingakat percepatan uang di Indonesia adalah model stokastic dan penelitian ini menggunakan metode ekonometrika model Koreksi Kesalahan (Error Correction Model) Model ECM ini memiliki beberapa nilai keunggulan dibandingkan model yang lain. Keunggulan model ECM 
yaitu dapat menganalisis jangka pendek dan jangka Panjang, dapat mengkaji konsistensi teori ekonomi serta dapat mengatasi masalah variabel yang waktunya tidak stasioner (time series) (Thomas, 1997).

Model:

$$
V_{t}=\beta_{0}+\beta_{1} \ln \text { emoney }+\beta_{2} \ln \text { Yperkapita }{ }_{t}+\beta_{3} i_{t}+e_{t}
$$

Dimana:

$$
\begin{array}{ll}
V & =\text { Velocity of money } \\
\ln \text { emoney } & =\text { logaritma natural transaksi electronic money } \\
\ln \text { Yperkapita } & =\text { logaritma natural dari tingkat pendapatan } \\
i & =\text { tingkat suku bunga } \\
\mathrm{t} & =\text { waktu } \\
\mathrm{e} & =\text { eror }
\end{array}
$$

\section{Pendekatan Error Correction Model (ECM)}

Penelitian ini dilakukan untuk mengetahui pengaruh variabel bebas atau independen seperti (transaksi electronic money, tingkat pendapatan dan tingkat suku bunga) terhadap variabel terikat atau dependen yaitu velocity of money atau kecepatan perputaran uang, maka digunakan Teknik analisis ECM untuk mengetahui jangka panjang dan jangka pendek dengan menggunakan software Eviews 9.

Metode ECM ini digunakan karena memiliki beberapa keunggulan yaitu analisis ini dapat melihat jangka panjang, jangka pendek, bisa menguji kointegrasi teori ekonomi dan ECM juga bisa menghindari regresi semu yang bisa menghasilkan kesimpulan yang menyesatkan. ECM memiliki beberapa proses analisis yang akan dilakukan yaitu deskriptif uji akar (testing for unit root), uji kointegrasi (Cointegrasi test), pendekatan ECM (Error Correction Model), uji asumsi klasik dan analisis ekonomi.

\section{Hasil dan Pembahasan}

Data Bank Indonesia menunjukkan ada kecenderungan pada pemakaian sistem pembayaran non tunai yang semakin diminati oleh masyarakat di Indonesia, hal ini dapat terlihat dari adanya peningkatan transaksi electronic money yang beredar di masyarakat. Peningkatan terbesar terjadi tahun 2017q4 yaitu sebesar 23.163.529 satuan pengguna electronic money. Rata - rata penggunaan electronic money terus meningkat dalam setiap tahunnya namun terjadi penurunan pada tahun 2014q2 dan 2016q1.

\section{Analisis Model dan Pengujian Hipotesis}

Model ECM yang digunakan dalam penelitian ini adalah:

$$
V_{t}=\beta_{0}+\beta_{1} \ln \text { emoney }+\beta_{2} \ln \text { Yperkapita }{ }_{t}+\beta_{3} i_{t}+e_{t}
$$

Dimana:

$$
\begin{array}{ll}
V & =\text { Velocity of money } \\
\ln \text { emoney } & =\text { logaritma natural transaksi electronic money }
\end{array}
$$




$$
\begin{array}{ll}
\ln \text { Yperkapita } & =\text { logaritma natural tingkat pendapatan } \\
i & =\text { tingkat suku bunga } \\
\mathrm{t} & =\text { waktu } \\
\mathrm{e} & =\text { eror }
\end{array}
$$

\section{Deskriptif Statistik}

Tabel berikut merupakan deskripsi statistik data dalam penelitian ini. Table 1 deskriptif statistik menunjukkan beberapa penjelasan dari variabel penelitian yang meliputi notasi, mean, median, minimum, maksimum dan standart deviasi data variabel penelitian.

Tabel 1: Deskriptif Statistik

\begin{tabular}{llccccc}
\hline Variabel & Notasi & Mean & Median & Min & Max & Stddev \\
\hline Velocity & $\mathrm{V}$ & 1.25447 & 1.18393 & 0.76435 & 1.83098 & 0.31235 \\
\hline $\begin{array}{l}\text { Transaksi } \\
\text { emoney }\end{array}$ & Inemoney & $155,395,237$ & $47,944,050$ & $5,927,416$ & $931,183,37$ & $226,875,46$ \\
\hline Yperkapita & InYperkapita & $10,332,960$ & $10,411,924$ & $6,631,700$ & $14,329,964$ & $2,151,780$ \\
\hline \hline Tingkat suku & I & 14.14585 & 14.18561 & 13.1013 & 15.35935 & 0.80020 \\
\hline
\end{tabular}

Sumber: Hasil Pengolahan dengan Eviews9

\section{Uji Stasioneritas Data}

Tabel 2: Hasil Uji Stasioner Tingkat Level

\begin{tabular}{ccc}
\hline Variable & Prob. & Max lag \\
\hline $\mathrm{V}$ & 0.9926 & 8 \\
\hline Lnemoney & 0.9798 & 8 \\
\hline InYperka & 0.0774 & 8 \\
\hline $\mathrm{p} \mathrm{I}$ & 0.0260 & 8 \\
\hline Method & Statistic & Prob.** \\
\hline ADF-Fisher Chi-square & 12.4757 & 0.1312 \\
\hline ADF-Choi Z-stat & 0.5595 & 0.7121 \\
\hline
\end{tabular}

Hasil pengujian stasioner pada Table 2 dengan metode Augmented Dickey - Fuller test (ADF) akan menghasilkan variabel apa saja yang stasioner. Variabel yang stasioner dinilai atau tidak akan terlihat dari nilai probabilitasnya. Masing-masing variabel yang ada yaitu $\mathrm{V}$ (0.9926), Inemoney (0.9798), InYperkap (0.0774), dan i (0.0260). Variabel dikatakan stasioner atau tidak ada akar unit jika nilai probabilitas kurang dari 1\%, 5\%, dan $10 \%$. Hasil uji di atas menunjukkan hanya variabel $v$ yang stasioner maka perlu dilanjutkan pada tingkat First different.

Hasil pengujian stasioner pada Table 3 dengan metode Augmented Dickey - Fuller test (ADF) akan menghasilkan variabel apa saja yang stasioner. Variabel yang stasioner atau tidak akan terlihat dari besaran nilai probabilitasnya. Masing - masing variabel yaitu $D(v) \quad 0.0000$, $\mathrm{D}$ (Inemoney) 0.0001 , D(InYperkap) 0.0000 , dan $\mathrm{D}$ (i) 0.0000 . Variabel diatas sudah dikatakan stasioner karena nilai atau tidak ada akar unit dan nilai probabilitas tidak lebih dari 0.05. 
Tabel 3: Hasil Uji Stasioner Tingkat First Difference

\begin{tabular}{cccc}
\hline \multicolumn{3}{c}{ Dependent Variabel : VELOCITY } \\
\hline Variabel & Prob. & Max lag \\
\hline $\mathrm{D}(\mathrm{V})$ & 0.0000 & 1 & 8 \\
$\mathrm{D}$ (Lnemoney) & 0.0001 & 8 & 8 \\
$\mathrm{D}$ (InYperkap) & 0.0000 & 1 & 8 \\
$\mathrm{D}(\mathrm{i})$ & 0.0000 & 0 & 8 \\
\hline Method & Statistic & & Prob. ${ }^{* *}$ \\
\hline ADF-Fisher Chi- & 116.283 & & 0.000 \\
square & & & 0.000 \\
\hline ADF-Choi Z-stat & -9.69973 &
\end{tabular}

Hasil pengujian stasioner pada Table 3 dengan metode Augmented Dickey - Fuller test (ADF) akan menghasilkan variabel apa saja yang stasioner. Variabel yang stasioner atau tidak akan terlihat dari besaran nilai probabilitasnya. Masing - masing variabel yaitu $\mathrm{D}$ (v) 0.0000, $\mathrm{D}$ (Inemoney) $0.0001, \mathrm{D}$ (InYperkap) 0.0000, dan $\mathrm{D}(\mathrm{i}) \quad 0.0000$. Variabel diatas sudah dikatakan stasioner karena nilai atau tidak ada akar unit dan nilai probabilitas tidak lebih dari 0.05 .

Hasil beberapa variabel diatas dapat disimpulkan bahwa semua variabel $D(v), D($ Inemoney), $\mathrm{D}$ (Yperkap) dan $\mathrm{D}(\mathrm{i})$ yang data sudah stasioner ditingkat 5\%. Maka data bisa dilanjutkan untuk di uji ECM jangka panjang.

\section{Estimasi Jangka Panjang}

Uji ECM jangka panjang dilakukan dengan cara Uji kointegrasi yang berawal dengan metode Ordinary Least Square (OLS). Metode OLS adalah metode yang digunakan untuk memperkirakan hubungan variabel, fungsi populasi dari fungsi regresi sampel. Metode ini juga dapat memperkirakan hubungan atau keterkaitan antar variabel penelitian dalam jangka panjang. Maka berikut hasil regresi Ordinary Least Square (OLS) untuk jangka panjang.

Hasil persamaan pada Table 4 dapat diketahui bahwa nilai coefisien persamaan adalah -14.21. Persamaan diatas juga menampilkan beberapa hasil variabel yaitu variabel volume electronic money memiliki pengaruh terhadap kecepatan perputaran uang atau velocity of money tetapi nilai pengaruhnya positif sebesar 0.116 , variabel pendapatan memiliki pengaruh terhadap kecepatan perputaran uang tetapi nilai pengaruhnya positif sebesar 0.652 , dan terakhir variabel tingkat suku bunga memiliki pengaruh terhadap kecepatan perputaran uang dan memiliki nilai pengaruh yang positif sebesar 0.030 Nilai dari $R^{2}$ persamaan diatas adalah 0.974 dapat disimpulkan bahwasanya variabel independent dapat menerangkan varaibel dependen sebesar 0.974 dan sisanya diterangkan oleh faktor lain.

Tabel 4: Hasil Estimasi Jangka Panjang

\begin{tabular}{ccc}
\hline \multicolumn{3}{c}{ Dependent Variabel : VELOCITY } \\
\hline Variabel & Koefisien & Prob. \\
\hline Lnemoney & 0.116 & 0.000
\end{tabular}




\begin{tabular}{ccc}
\hline \multicolumn{3}{c}{ Dependent Variabel : VELOCITY } \\
\hline Variabel & Koefisien & Prob. \\
\hline LnYperkap & 0.652 & 0.002 \\
I & 0.030 & 0.001 \\
C & -14.21 & 0.000 \\
R-squared & & 0.97 \\
Adj R-squared & & 0.97 \\
\hline \hline
\end{tabular}

Hasil persamaan pada Table 4 dapat diketahui bahwa nilai coefisien persamaan adalah -14.21. Persamaan diatas juga menampilkan beberapa hasil variabel yaitu variabel volume electronic money memiliki pengaruh terhadap kecepatan perputaran uang atau velocity of money tetapi nilai pengaruhnya positif sebesar 0.116 , variabel pendapatan memiliki pengaruh terhadap kecepatan perputaran uang tetapi nilai pengaruhnya positif sebesar 0.652 , dan terakhir variabel tingkat suku bunga memiliki pengaruh terhadap kecepatan perputaran uang dan memiliki nilai pengaruh yang positif sebesar 0.030 Nilai dari $R^{2}$ persamaan diatas adalah 0.974 dapat disimpulkan bahwasanya variabel independent dapat menerangkan varaibel dependen sebesar 0.974 dan sisanya diterangkan oleh faktor lain.

Setelah melakukan metode Ordinary Least Square (OLS) tahap selanjutnya adalah melakukan pengujian untuk mencari nilai residual dari persamaan pada penelitian. Tahapan pencarian nilai residual disebut sebagai uji kointegrasi. Uji kointegrasi adalah pencarian nilai dari residual yang stasioner atau dapat dikatakan bahwa uji kointegrasi dilakukan untuk melihat apakah data dapat diuji menggunakan ECM atau tidak. Syarat uji kointegrasi harus dilakukan agar uji ECM dapat dilakukan

Table 5: Uji Kointegrasi

\begin{tabular}{llllll}
\hline Variable & $\begin{array}{l}\text { ADF test } \\
\text { statistic }\end{array}$ & \multicolumn{4}{l}{$\begin{array}{l}\text { McKinnon Criti- } \\
\text { cal Values }\end{array}$} \\
\hline & intercept & Prob. & $1 \%$ & $5 \%$ & $10 \%$ \\
\hline ECT $(-1)$ & -0.380 & 0.008 & -3.632 & -2.948 & -2.612 \\
\hline
\end{tabular}

Sumber: Hasil Pengolahan dengan Eviews9

Menurut hasil Table 5 dapat disimpulkan bahwa antar variabel telah terjadi signfikan kointegrasi dalam jangka panjang dengan memiliki probabilitas 0,008 . Metode OLS dapat dikatan berhasil karena teruji berhasil dan hasil OLS tersebut dapat disimpulkan menjadi hasil jangka panjang dari persamaan tersebut.

\section{Estimasi Jangka Pendek}

Tabel 6: Hasil Estimasi Jangka Pendek

\begin{tabular}{lcl}
\hline \multicolumn{3}{c}{ Dependent Variabel : VELOCITY } \\
\hline Variabe & Koefisien & Prob. \\
\hline $\mathrm{D}$ (Inemoney) & 0.023 & 0.454 \\
\hline $\mathrm{D}$ (InYperkap) & 0.921 & 0.000 \\
\hline $\mathrm{D}(\mathrm{i})$ & 0.011 & 0.027 \\
\hline $\mathrm{ECT}(-1)$ & -0.291 & 0.013 \\
\hline $\mathrm{C}$ & 0.006 & 0.440 \\
\hline
\end{tabular}




\begin{tabular}{lll}
\hline \multicolumn{2}{c}{ Dependent Variabel : VELOCITY } \\
\hline Variabe & Koefisien & Prob. \\
\hline R-squared & 0.552 \\
\hline Adj. R-Squared & 0.492 \\
\hline
\end{tabular}

$$
\begin{aligned}
& \Delta V_{t}=\beta_{0}+\beta_{1} \Delta \ln \text { money }_{t}+\beta_{2} \text { Yperkap }_{t}+\beta_{3} \Delta i_{t}+\beta_{4} \Delta U_{t-1}+e_{t} \\
& \Delta V_{t}=0.006+0.023 \Delta \ln \text { money }_{t}+0.921 \text { Yperkap }_{t}+0.011 \Delta i_{t}+0.291 \Delta U_{t-1}+e_{t}
\end{aligned}
$$

Hasil persamaan pada Table 6 dapat diketahui bahwa nilai coefisien persamaan adalah 0.006. Persamaan diatas juga menampilkan beberapa hasil variabel yaitu variabel transaksi electronic money tidak memiliki pengaruh terhadap kecepatan perputaran uang dan nilai pengaruhnya positif sebesar 0.023 , variabel pendapatan memiliki pengaruh terhadap kecepatan perputaran uang dan nilai pengaruhnya positif sebesar 0.921 , dan terakhir variabel tingkat suku bunga memiliki pengaruh terhadap kecepatan perputaran uang tetapi memiliki nilai pengaruh yang positif sebesar 0.011 .

Hasil persamaan pada Table 7 dapat diketahui bahwa nilai coefisien persamaan adalah -10.09. Persamaan diatas juga menampilkan beberapa hasil variabel yaitu variabel rasio volume electronic money yang memiliki pengaruh terhadap kecepatan perputaran uang atau velocity of money tetapi nilai pengaruhnya positif sebesar 0.116 , variabel pendapatan juga memiliki pengaruh terhadap kecepatan perputaran uang tetapi nilai pengaruhnya positif sebesar 0.652 , dan terakhir variabel mengenai tingkat suku bunga memiliki pengaruh terhadap kecepatan perputaran uang dan memiliki nilai pengaruh yang positif sebesar 0.030 Setelah melakukan metode Ordinary Least Square (OLS) tahap selanjutnya adalah melakukan pengujian kointegrasi dengan mencari nilai residual dari persamaan di penelitian.

Table 8: Uji Kointegrasi

\begin{tabular}{cccccc}
\hline Variable & $\begin{array}{c}\text { ADF test } \\
\text { statistic }\end{array}$ & \multicolumn{4}{c}{$\begin{array}{c}\text { McKinnon Criti- } \\
\text { cal Values }\end{array}$} \\
\hline & intercept & Prob. & $1 \%$ & $5 \%$ & $10 \%$ \\
\hline ECT $(-1)$ & -0.380 & 0.008 & -3.632 & -2.948 & -2.612 \\
\hline
\end{tabular}

Sumber: Hasil Pengolahan dengan Eviews9

Menurut hasil dari Table 8 dapat disimpulkan bahwa antar variabel telah terjadi signfikan kointegrasi dalam jangka panjang dengan memiliki probabilitas 0,008. Metode OLS dapat dikatan berhasil karena teruji berhasil dan hasil OLS tersebut dapat disimpulkan menjadi hasil jangka panjang dari persamaan tersebut.

\section{Estimasi Jangka Pendek}

Hasil persamaan pada Table 9 dapat diketahui bahwa nilai coefisien persamaan adalah 0.006 .

Tabel 9: Hasil Estimasi Jangka Pendek

\begin{tabular}{ccc}
\hline \multicolumn{3}{c}{ Dependent Variabel : VELOCITY } \\
\hline Variabel & Koefisien & Prob. \\
\hline $\mathrm{D}$ (Inemoney) & 0.023 & 0.454
\end{tabular}




\begin{tabular}{ccc}
\hline \multicolumn{3}{c}{ Dependent Variabel : VELOCITY } \\
\hline Variabel & Koefisien & Prob. \\
\hline D(InYperkap) & 0.921 & 0.000 \\
D(i) & 0.011 & 0.027 \\
ECT(-1) & -0.291 & 0.013 \\
$C$ & 0.006 & 0.440 \\
R-squared & & 0.552 \\
\hline \hline Adj R-squared & & 0.492 \\
\hline \hline
\end{tabular}

$$
\begin{aligned}
& \Delta V_{t}=\beta_{0}+\beta_{1} \Delta \ln \text { money }_{t}+\beta_{2} \text { Yperkap }_{t}+\beta_{3} \Delta i_{t}+\beta_{4} \Delta U_{t-1}+e_{t} \\
& \Delta V_{t}=0.006+0.023 \Delta \ln \text { money }_{t}+0.921 \text { Pperkap }_{t}+0.011 \Delta i_{t}+0.291 \Delta U_{t-1}+e_{t}
\end{aligned}
$$

Persamaan diatas juga menampilkan beberapa hasil variabel yaitu variabel rasio transaksi electronic money tidak memiliki pengaruh terhadap kecepatan perputaran uang dan nilai pengaruhnya positif sebesar 0.023 , variabel pendapatan memiliki pengaruh terhadap kecepatan perputaran uang dan nilai pengaruhnya positif sebesar 0.921 , dan terakhir variabel tingkat suku bunga memiliki pengaruh terhadap kecepatan perputaran uang tetapi memiliki nilai pengaruh yang positif sebesar 0.011 . Nilai dari $R^{2}$ persamaan diatas adalah 0.552 dapat disimpulkan bahwa variabel independent dapat menerangkan varaibel dependen sebesar 0.552 dan sisanya diterangkan oleh faktor lainnya.

\section{Pembahasan}

Hasil estimasi pada penelitian yang dilakukan mengungkapkan keterkaitan antara variabel independen terhadap variabel dependen. Penelitian ini menggunakan variabel velocity of money menjadi variabel dependen dan variabel transaksi yaitu electronic money, pendapatan perkapita dan tingkat suku bunga menjadi variabel independent. Hasil estimasi penelitian ini menggunakan periode tahun 2010 - 2018 dengan menggunakan data quartal atau data triwulan (per 3 bulan). Penelitian ini menggunakan metode ECM yang menghasilkan estimasi jangka panjang dan jangka pendek.

Pada estimasi jangka panjang yang juga menggungkapkan keterkaitan antara variabel independent terhadap variabel dependen. Variabel independennya yaitu variabel transaksi electronic money, juga tingkat pendapatan, tingkat suku bunga. Pertama variabel transaksi electronic money ternyata memiliki pengaruh yang signifikan terhadap kecepatan perputaran uang dan koefisiennya positif atau dapat dikatan electronic money dapat mempercepat kecepatan perputaran uang, dengan hasil regresi seperti ini dapat dijelaskan dengan teori dari Irving Fisher dan hasil empiris. Teori Irving Fisher menyatakan bahwa velocity of money akan berubah jika alat transaksinya berubah. Hasil empiris yang mendukung hasil regresi ini adalah bahwa perkembangan electronic money yang ada di Indonesia masih dalam proses perkembang dan masyarakat Indonesia sudah percaya dengan uang elektronik. Menggunakan uang elektronik dapat membuat traksaksi atau kegiatan ekonomi lebih efisien. Uang elektronik sendiri memiliki kelebihan aman dibawa, lebih mudah dalam transaksi dan dengan begitu masyarakat sudah mulai menggunakannya dalam kegiatan sehari-hari. Peningkatan kepercayaan pada jenis uang elektronik sebagai salah satu alat transaksi akan mempercepat perputaran uang dengan begitu akan menambah output negara.

Variabel pendapatan perkapita yang ternyata memiliki pengaruh yang signifikan terha- 
dap kecepatan perputaran uang dan nilai dari koefisien variabel ini adalah positif dalam jangka panjang. Hasil ini didukung dengan teori Keynes konsumsi rata - rata yang dipengaruhi oleh pendapatan, lalu menurut teori moneter yang ditemukan oleh Irving Fisher yaitu transaction velocity approach yang berisi tentang pada alasan mengapa orang membelanjakan uangnya serta dapat berpengaruh terhadap kecepatan perputaran uang.

Variabel tingkat suku bunga ternyata memiliki pengaruh terhadap kecepatan perputaran uang atau velocity of money dan nilai koefisiennya pun positif dalam jangka panjang. Asumsi hasil penelitian ini didukung oleh teori permintaan uang oleh Keynes yang menyatakan bahwa hubungan antara tingkat suku bunga dengan kecepatan perputaran uang adalah positif.

Pada hasil estimasi jangka pendek juga menggungkapkan bahwa keterkaitan variabel independent terhadap variabel dependen. Variabel independennya antara lain variabel transaksi yaitu electronic money, tingkat pendapatan, dan juga tingkat suku bunga. Pertama variabel transaksi electronic money ternyata memiliki pengaruh tetapi yang sedikit terhadap kecepatan perputaran uang pada jangka pendek. Hasil ini didukung oleh teori empiris yang menyatakan bahwa volume uang elektronik masih dalam tahapan berkembang dan uang elektronik masih terfokus kota-kota besar di negara Indonesia karena adanya kepercayaan seseorang kepada jenis uang elektronik masih belum sepenuhnya.

Variabel pendapatan perkapita ternyata memiliki pengaruh yang signifikan terhadap percepatan uang dalam jangka pendek. Hasil ini didukung dengan teori Keynes adalah tingkat konsumsi marjinal atau yang disebut dengan kecendrungan konsumsi rata - rata yang dipengaruhi oleh pendapatan, lalu menurut teori moneter yang ditemukan oleh Irving Fisher yaitu transaction velocity approach yang berisi tentang pada alasan mengapa orang membelanjakan uangnya serta berpengaruh tersebut pada kecepatan perputaran uang.

Variabel tingkat suku bunga ternyata memiliki pengaruh terhadap kecepatan perputaran uang atau velocity of money dan nilai koefisiennya positif dalam jangka pendek dan dapat dikatakan bahwa variabel tingkat suku bunga berpengaruh dalam jangka pendek. Asumsi hasil penelitian ini didukung oleh teori permintaan uang oleh Keynes yang memikiki pernyataan bahwa hubungan antara tingkat suku bunga dengan kecepatan perputaran uang adalah positif.

\section{Kesimpulan dan Saran}

Berdasarkan hasil analisis dan pembahasan penelitian ini dapat diambil kesimpulan sebagai berikut:

1. Berdasarkan hasil estimasi jangka panjang dan jangka pendek pada variabel transaksi yaitu electronic money yang mengungkapkan bahwa ternyata variabel tersebut berpengaruh signifikan pada jangka panjang dan jangka pendek hanya berpengaruh kecil (sedikit). Transaksi electronic money memiliki pengaruh terhadap kecepatan perputaran uang. Pada jangka panjang koefisiennya positif dan jangka pendek ternyata memiliki nilai koefisien yang positif dapat disimpulkan bahwa ternyata electronic money dapat meningkatkan kecepatan perputaran uang,

2. Berdasarkan hasil estimasi jangka panjang dan jangka pendek variabel seperti tingkat pendapatan memiliki pengaruh pada jenis jangka panjang maupun jangka pendek. Hasil ini didukung dengan teori Keynes bahwa tingkat konsumsi marjinal atau yang disebut dengan kecenderungan konsumsi rata - rata dipengaruhi oleh pendapatan, lalu menurut teori mon- 
eter yang ditemukan oleh Irving Fisher yaitu transaction velocity approach yang berisi tentang pada alasan mengapa orang membelanjakan uangnya serta berpengaruh pada kecepatan perputaran uang.

3. Berdasarkan hasil estimasi yang jangka panjang dan juga jangka pendek variabel tingkat suku bunga memiliki pengaruh terhadap tingkat kecepatan perputaran uang pada jangka panjang saja dan nilai koefisiennya adalah positif. Hasil ini didukung oleh teori dari Keynesian yang menyatakan bahwa hubungan anatara tingkat suku bunga dengan permintaan uang adalah positif.

Keterbatasan Penelitian ini adalah data transaksi electronic money di Indonesia yang masih sedikit atau masih berkembang karena electronic money di Indonesia masih baru ada pada tahun 2009 dan terbilang masih berkembang dibandingkan dengan negara lainnya.

\section{Saran}

Penelitian ini memiliki beberapa hal yang dapat direkomendasikan untuk pengambil kebijakan serta untuk penelitian selanjutnya antara lain:

Saran untuk pengambil kebijakan:

Perkembangan transaksi electronic money sudah semakin berkembang dan perlu untuk ditingkatkan untuk infrastruktur electronic money agar orang yang lebih percaya dengan uang elektronik dan dengan masyarakat percaya dengan uang elektronik akan dapat mempercepat transaksi bisa terwujud.

Saran untuk penelitian selanjutnya :

Penelitian selanjutnya diharapkan bisa menggunakan data cross country diantara negara berkembang.

\section{Daftar Pustaka}

Aiba, D. (2018). Foreign Currency Borrowing and Risk-Hedging Behaviors: Evidence from a Household Survey in Cambodia. Journal of Asian Economics, 58, hh.19-35.

Andresen, T. (2013). Improved macreconomic control with electronic money and modern monetary theory. real-world economics review.

Burke, R. R. (2002). Technology and the Customer Interface: What Consumers Want in the Physical and Virtual. Journal of the Academy of Marketing Science. , 30(4), hh.411-432.

Cardak, B. (2009). The Determinants Of Household Assets Holdings. Journal of banking \& Finance, 33(5), hh.850-860.

Dimand, R.W. and Gomez Betancourt, R., (2012). Retrospectives: Irving Fisher's Appreciation and Interest (1896) and the Fisher Relation. Journal of Economic Perspectives, 26(4), hh.185-96.

Durgun, Ö. and Timur, M.C. (2015). The effects of electronic payments on monetary policies and central banks. Procedia-Social and Behavioral Sciences, 195(195).

Fisher, I. (2006). The Purchasing Power Of Money: Its' Determination And Relation To Credit Interest And Crises. New York: Cosimo, Inc.

Friedman, M. (1956). The Quantity Theory of Money: A Restatement. Studies in The Quantity 
Theory Of Money, 5. Chicago: University of Chicago

Fujiki, H. and Tanaka, M. (2014). Currency demand, new technology, and the adoption of electronic money: Micro evidence from Japan. Economics letters, 125(1), hh.5-8.

Gichuki, C.N. and Mulu-Mutuku, M. (2018), March. Determinants of awareness and adoption of mobile money technologies: Evidence from women micro entrepreneurs in Kenya. In Women's Studies International Forum (Vol. 67, hh. 18-22). Pergamon.

Griffith, R., (2012). Electronic Money and Monetary Policy. Southwestern Economic Proceedings, 31(2), hh.47-56.

Halpin, R. and Moore, R. (2009). Developments in electronic money regulation-the Electronic Money Directive: A better deal for e-money issuers?. Computer Law \& Security Review, 25(6), hh.563-568.

Hervé, F., Zouaoui, M. and Belvaux, B., (2019). Noise traders and smart money: Evidence from online searches. Economic Modelling, 83, hh.141-149.

Hidayati, S., Nuryanti, I., Firmansyah, A., Fadly, A., \& Darmawan, I. Y. (2006). Operasional e-money. Jakarta, Indonesia: Bank Indonesia.

Humphrey, D.B., Pulley, L.B. and Vesala, J.M., (1996). Cash, paper, and electronic payments: a cross-country analysis. Journal of Money, Credit and Banking, 28(4), hh.914-939.

Keynes, J.M., (2018). The general theory of employment, interest, and money. Springer.

Khan, J. and Craig-Lees, M., (2009). 'Cashless' transactions: perceptions of money in mobile payments. International Business and Economics Review.

Mbiti, I. and Weil, D.N., (2013). The home economics of e-money: velocity, cash management, and discount rates of M- Pesa users. American Economic Review, 103(3), hh.369-74.

Mishkin, F. (2004). The Economics of Money, Banking, and Financial Markets. New Jersey: Pearson.

Poon, S. and Chau, P.Y., (2001). Octopus: the growing e-payment system in Hong Kong. Electronic markets, 11(2), hh.97- 106.

Raghubir, P. and Srivastava, J., (2008). Monopoly money: The effect of payment coupling and form on spending behavior. Journal of experimental psychology: Applied, 14(3), p.213.

Ranjan, R.P. and Kar, R., (2014). The Dynamics of Money Velocity, External Sectors and Electronic Transactions in India: Connecting dots using Empirical Approach. Journal of Applied Economics \& Business Research, 4(3).

Riley, E., (2018). Mobile money and risk sharing against village shocks. Journal of Development Economics, 135, hh.43-58.

See-To, E.W. and Ngai, E.W., (2018). An empirical study of payment technologies, the psychology of consumption, and spending behavior in a retailing context. Information \& Management, 56(3), hh.329-342.

Singh, S., (1999). Electronic money: understanding its use to increase the effectivenes of policy. Telecommunications Policy, 23(10-11), hh.753-773. 
Solomon, E., (1999). What should regulators do about consolidation and electronic money?. Journal of Banking \& Finance, 23(2-4), hh.645-653.

Suri, Tavneet \& Jack, W. (2016). The Long-Run Poverty and Genderimpacts of Mobile Money. Development Economics, 354(6317), 1288-1292.

Thomas, R.L. (1997). Modern Econometrics an Introduction. New York: Addison Wesley Publishing Company, Inc.

Zayer, A. H., \& Mohammed Al- Tweel, T. T. (2019). The impact of electronic payment systems on the velocity of money circulation.

Zhou, K.Z. and Wu, F. (2010) Technological Capability, Strategic Flexibility, and Product Innovation. Strategic Management Journal, 31, 547-561. 